\title{
Beyin Temelli Öğrenmeye Dayalı Web Destekli Öğretim Materyalinin Etkililiğinin Değerlendirilmesi: 'Yer Kabuğu Nelerden Oluşur? ${ }^{*}$
}

\author{
Evaluation of Effectiveness of a Web- Based Instructional Material According to \\ Brain Based Learning: "What Does the Earth's Crust Consists of?"
}

\author{
Hava İPEK AKBULUT ${ }^{* *}$ \\ Çiğdem ŞAHİN ${ }^{* * *}$ \\ Esra KELEŞ ${ }^{* * *}$
}

\begin{abstract}
$\ddot{\mathbf{O z}}$
Çalışmanın amacı ilköğretim 6. sınıf Fen ve Teknoloji dersi öğretim programında yer alan "Yer kabuğu nelerden oluşur?” ünitesindeki konuların ve kavramların öğretimine yönelik geliştirilen beyin temelli öğrenme yaklaşımına dayalı web destekli öğretim materyalinin öğrenci başarısı üzerindeki etkisini, öğrencilerin ve öğretmenin WDÖ materyali hakkındaki görüşlerini araştırmaktır. Çalışmada karma araştırma yöntemi kullanılmıştır. Çalışmanın örneklemini 6. sınıfta öğrenim gören 58 öğrenci oluşturmaktadır. Çalışmanın verileri; 'Yer kabuğu nelerden oluşur?' ünitesi başarı testi ve yarı yapılandırmış mülakat sorularından elde edilmiştir. Araştırma sonucunda deney grubunda uygulanan web destekli öğretim materyalinin, kontrol grubunda uygulanan mevcut öğretim materyallerine oranla öğrencilerinin akademik başarılarını arttırmada $\left(t_{(56)}=2,27 ; \mathrm{p}<.05\right)$ etkili olduğu sonucuna ulaşılmıştır. Ayrıca öğrencilerin web destekli öğretimden memnun kaldıkları, uygulama öğretmeninin her ne kadar WDÖ’yü etkili bulsa da bir takım dezavantajlarının da olduğunu belirttiği dikkat çekmektedir.
\end{abstract}

Anahtar Kelimeler: Web destekli öğretim, beyin temelli öğrenme, fen öğretimi, yer kabuğu.

* Bu çalışma Karadeniz Teknik Üniversitesi Bilimsel Araştırma Projeleri Birimi tarafından desteklenen (Proje Kod No: 2008.116.007.2.) İlköğretim 6. Sınıf Fen ve Teknoloji Dersi Öğretim Programına Yöne-lik Beyin Temelli Öğrenmeye Dayalı Web Destekli Öğretim Materyalinin Geliştirilmesi Projesỉnin bir bölümünü içermektedir

* Dr. Öğr. Üyesi, Karadeniz Teknik Üniversitesi, Fatih Eğitim Fakültesi, havaipek@gmail.com

* Doç. Dr., Giresun Üniversitesi, Eğitim Fakültesi, hcsahin38@gmail.com

* Dr. Öğr. Üyesi, Karadeniz Teknik Üniversitesi, Fatih Eğitim Fakültesi, esrakeles1461@hotmail.com 


\section{Abstract}

The purpose of this study was to develop a web based instructional material according to brain based learning approach for concepts and topics of 6th grade "what the earth's crust consists of?" unit and to investigate the effects of this material and the views of students and teachers about web based material. Mixed research was used in this study. The sample of this study consisteds of 58 6th grade students. Data of the study obtained from 'What the earth's crust consists of?' unit achievement test, semi-structured interviews. At the end of the study, it was found that webbased material applied to experiment group hasd a meaningful statistically significant difference on increasing achievement than the existing instructional material applied to control group $(\mathrm{t}(56)$ $=2,27 ; \mathrm{p}<.05)$. In addition, students weare satisfied with their web supported training, although the application teacher who implemented the material thought that web- based instruction is effective but they stated that web- based instructional has some disadvantages.

Keywords: Web based instruction, brain based learning, science teaching, earth's crust.

\section{Giriş}

Fen bilimleri birçok soyut kavram içeren bir derstir. Bu nedenle öğrenciler, günlük hayatta bu kavramlara ilişkin durumlar ile sıklıkla karşılaşmalarına rağmen, dersteki soyut kavramları açıklamakta zorlanmaktadır (Durmaz, 2004). Öğrencilerin bu problemlerini çözmek ve fen bilimleri dersini daha anlaşılır hale getirmek amacıyla, öğretim programları sıklıkla güncellenmektedir. 2005 yılında fen ve teknoloji öğretim programı, öğrenci merkezli eğitim anlayışını benimsemekte ve eleştirel düşünebilen, araştırmacı, sorgulayan bireyler yetiştirmeyi amaçlamaktadır. Bu programda "canlılar ve hayat", "madde ve değişim", "fiziksel olaylar" ile "dünya ve evren” olmak üzere 4 öğrenme alanı bulunmaktadır. İlköğretim Fen ve Teknoloji Öğretim Programinnda; ünitelendirilmiş bu öğrenme alanları içerisinde yer alan konu ve kavramlar, sarmallık ilkesine bağlı kalınarak işlenmektedir (Milli Eğitim Bakanlığı, 2006). Sarmallık ilkesine göre; temel kavramlar iyi bir şekilde öğrenildiğinde, sonraki yıllarda konu ile ilgili kavramların etkili bir şekilde öğrenilebileceği düşünülmektedir. Temel kavramların yer aldığı ünitelerden birisi de 'Yer kabuğu nelerden oluşur?' ünitesidir. Mevcut alanyazın incelendiğinde öğrencilerin 'Yer kabuğu nelerden oluşur?' ünitesi içerisinde yer alan; kayaç çeşitleri, fosiller, toprak çeşitleri ve erozyon, yer altı ve yer üstü suları konuları ile ilgili bazı alternatif kavramlara sahip oldukları tespit edilmiştir (Dove, 1997; Bozkurt, Salman Akın \& Uşak, 2004; Blake, 2004; Blake, 2005; Ford, 2005; Reinfried, 2006; Rosenberg, Hammer ve Phelan, 2006; Wardrip \& Tobey 2009; Dal, 2009). Blake (2005)'in çalışmasında çocukların kayaç tanımında bilimsel olmayan; komik şekilli, kirli, daire, taş gibi bilimsel olmayan kavramları kullandıkları tespit edilmiştir. Dal’ın (2009) çalışmasında ise öğrencilerin, kaya ve taş kavramlarını karıştırıldı̆̆ı tespit edilmiştir. Öğrenciler kayaçların kökeninin, fosillere dayandığını düşünmektedirler (İnci, Zorlu \& Çil, 2009). Öğrencilerin, bu temel kavramları doğru bir şekilde öğrenebilmeleri için, alternatif kavramların giderilmesinin gerekliliği ön plana çıkmaktadır. Alternatif kavramların, öğrencilerin kavramları doğru algılamasına ve kalıcı öğrenmenin sağlanmasına engel olduğu ve akademik başarılarını olumsuz etkilediği bilinmektedir (Ecevit \& Şimşek, 2017). Nitekim alternatif kavramların değişime karşı direnç gösterdiği, hatta 
yapılan öğretim sonunda bile bazı alternatif kavramların giderilemediği araştırma sonuçlarından bilinmektedir (Köseoğlu \& Kavak, 2001; Ayas \& Uşak, 2006; İpek Akbulut, Şahin \& Çepni, 2013). $\mathrm{Bu}$ noktada kavramsal değişimi sağlamada etkili öğretim materyallerine ihtiyaç duyulmaktadır. Öğretim materyalleri ile etkili kavramsal değişimi sağlamak için öğrencilerin sahip oldukları alternatif kavramların öğretim materyali uygulanmadan önce belirlenmesi ve öğretim materyalinin bu alternatif kavramları gidermeye yönelik olarak hazırlanması gerekmektedir (Çayan ve Karslı, 2015).

Alanyazında yapılandırmacı öğrenme, kavramsal değişim ve ikili yerleşik öğrenme yaklaşımı gibi farklı yaklaşımlara dayalı öğretim materyalleri geliştirilmekte ve öğrenmeye etkisi araştırılmaktadır (Şahin, 2010; İpek Akbulut, Şahin \& Çepni, 2013). Öğrenmenin gerçekleşmesinde etkili olduğu tespit edilen yaklaşımlardan birisi de Beyin Temelli Öğrenme (BTÖ) yaklaşımıdır (Keleş, 2007; Özden, 2005). Beyin ve sinir sistemi, öğrenmenin temelini oluşturmaktadır. Duyu organları ile algılanan faaliyetlerin beyinde ilişkilendirme, tekrarlama ve anlamlandırılması ile birlikte öğrenme gerçekleşir (Demirel, 2011). Beyin temelli öğrenme de, bu anlamlandırmanın doğru şekilde nasıl yapılacağı konusunda eğitimcilere yardımcı olmaktadır.

BTÖ yaklaşımında beynin işleyiş kuralları dikkate alınarak, öğretimin zihindeki bu kurallara göre yapılandırılması ve anlamlı öğrenmenin gerçekleşmesi amaçlanmaktadır (Caine \& Caine, 1994; Demirel, Erdem, Koç, Köksal \& Şendoğdu, 2002). Beyin temelli öğrenmede, nörobilime ilişkin bulgulardan elde edilen çıkarımların, öğretmenler tarafından öğretim etkinliklerine yansıtıldı̆̆ı bir süreç söz konusudur (Zadina, 2015). Beyin temelli öğrenme ile birlikte öğretmenler etkili ve kalıcı öğrenmeyi sağlamak için sınıf ortamını nasıl düzenleyeceklerini, konu ve kavramları nasıl öğreteceklerini belirleyebilirler (Erol, 2017). Beyin temelli öğrenmeye yönelik olarak öğretimi sağlayabilmek için, beyin temelli öğrenme ilkelerinin bilinmesi gerekmektedir. Beyin Temelli Öğrenme yaklaşımı ile ilgili 12 ilke bulunmaktadır. Bu ilkeler;

1. Beyin paralel bir işlemcidir.

2. Öğrenme fizyolojik bir olaydır.

3. Anlam arayışı içseldir.

4. Anlam arayışı örüntüleme (patterning) yoluyla oluşur.

5. Örüntülemede duygular çok önemlidir.

6. Beyin parçaları ve bütünü aynı anda algılar.

7. Öğrenme hem doğrudan odaklanılan, hem de yan uyarıcılardan algılanan bilgileri içerir.

8. Öğrenme bilinçli ve bilinç dişı süreçlerden oluşur.

9. İki tür bellek vardır: Uzamsal bellek ve sistemler dizisi.

10. Olgu ve beceriler uzamsal belleğe depolandığında daha iyi öğrenilir.

11. Öğrenme zihni zorlayan etkinliklerle gelişir, tehditle azalır.

12. Hiçbir beyin diğerine benzemez.

şeklinde sıralanmaktadır (Caine \& Caine, 1990). BTÖ, öğrencilerin çeşitli öğrenme durumları ve öğrenme içeriği ile karşılaştıkları ve kendi bilgilerini yapılandırdıkları aktif bir süreçtir (Duman, 
2006). Bu süreçte öğretmen, bilgiyi aktaran değil, öğrenmeyi kolaylaştıran bir rol üstlenmektedir. $\mathrm{Bu}$ doğrultuda beyin temelli öğrenmeyi uygulamak isteyen öğretmenlerin öğrencilerine; öğrenme deneyimlerini içselleştirme, bireyselleştirme imkânı tanımaları ve onların ilgilerini çekebilecek zengin öğrenme ortamlarını oluştursınıflarında görsel ve işitsel materyallerden, çeşitli modellerden, bilgisayar teknolojisinden ve simülasyonlardan yararlanmalıdır (Wolfe, 2004; Özden \& Gültekin, 2008). Bilgisayar ve internet teknolojilerinin eğitimde kullanımının; bireylere bilgiye istediği zamanda rahatlıkla ulaşma, sürekli etkileşimi sağlama gibi çeşitli avantajları bulunmaktadır (Biriş̧̧i \& Metin, 2009; Pool, 1997). Bu avantajlar düşünüldüğünde teknolojinin; beyin temelli öğrenme yaklaşımına göre oluşturulan öğrenme ortamlarında etkin bir biçimde kullanılmasının, öğrencilere katkı sağlayabileceğine inanılmaktadır. Öğretmen ve öğrencinin aynı öğrenme ortamını paylaştı̆̆ı ve internet üzerinden öğretimin yapıldığı web destekli öğrenme ortamları öğrenmeyi teknoloji yönünden desteklemektedir. Web destekli öğrenme ortamları ile öğrencilerin kavramsal öğrenmelerinde gelişim sağlamak ve bireysel ve grup etkinliklerle işbirlikli sorgulama yaklaşımının uygulamaya dökülmesi mümkündür (Sun, Looi \& Xie, 2014). Web destekli öğretim materyalleri, öğrencilere bireysel hızına göre kendi öğrenme sürecini yönetme olanağı vermektedir. Ayrıca bu öğrenme ortamları ile birlikte soyut olan fen konuları somutlaştırılmakta ve öğrencilerin anlamlı öğrenmeleri sağlanmaktadır (Ural \& Ercan, 2015). Bu şekilde anlamlı öğrenmeyi sağlamada etkili olan web destekli öğretim ve beyin temelli öğrenme yaklaşımlarının birlikte ele alındığı çalışmalar ise alanyazında az sayıdadır. Keleş (2007) ve Paliç \& Akdeniz (2012) tarafından yapılan çalışmalar buna örnek olarak verilebilir. Yapılan bu çalışmanın ise, 'Yer kabuğu nelerden oluşur?' ünitesindeki kavramların öğretimine yönelik Beyin Temelli Öğrenme yaklaşımına dayalı Web Destekli Öğretim materyalini içermesi sayesinde alanyazına katkı sağlayabileceği düşünülmektedir. Bu çerçevede çalışmanın amacı; illköğretim 6. sınıf Fen ve Teknoloji dersi öğretim programında yer alan 'Yer Kabuğu Nelerden Oluşur?' ünitesindeki konuların öğretimine yönelik geliştirilen Beyin Temelli Öğrenme yaklaşımına dayalı Web Destekli Öğretim materyalinin etkisini araştırmaktır. Bu temel amaç doğrultusunda aşağıdaki alt amaçlar belirlenmiştir:

1. Beyin Temelli Öğrenme yaklaşımına dayalı Web Destekli Öğretim materyali geliştirmek.

2. Beyin Temelli Öğrenme yaklaşımına dayalı Web Destekli Öğretim materyalinin öğrenci başarısı üzerindeki etkisini araştırmak.

3. Öğrencilerin ve uygulama öğretmeninin Beyin Temelli Öğrenme yaklaşımına dayalı Web Destekli Öğretim materyali hakkındaki görüşlerini belirlemek.

\section{Yöntem}

\section{Araştırmanın Modeli}

Bu çalışmada karma araştırma yöntemi kullanılmıştır. Karma yöntem, hem nitel hem de nicel verilerin toplanmasını ve analiz edilmesini içermektedir (Baki \& Gökçek, 2012; Büyüköztürk, Kılıç Çakmak, Akgün, Karadeniz \& Demirel, 2012; Creswell, 2006; Gökçek, Babacan, Kangal, Çakır \& Kül, 2013). Karma yöntemde nitel ve nicel veriler, ayrı ayrı (multiple studies) veya birleştirerek (single study) raporlaştırabilirler (Creswell, 2006). Bu araştırmada Beyin temelli 
öğrenme yaklaşımına dayalı web destekli öğretim materyalinin öğrenci başarısı üzerindeki etkisi, öğrencilerin ve öğretmenin Beyin temelli öğrenme yaklaşımına dayalı web destekli öğretim materyali hakkındaki görüşleri ayrı ayrı raporlaştırılmıştır. Bu amaca uygun olarak karma yöntem tasarımlarından gömülü desen benimsenmiştir. Bu desende nicel verileri genişletmek için nitel veriler toplanır (Plano-Clark, Huddleston-Casas, Churchill, O’Neil Green \& Garrett, 2008). Araştırmanın nicel kısmında Beyin temelli öğrenme yaklaşımına dayalı web destekli öğretim materyalinin etkisi araştırıldığından, nitel kısmında ise öğrenci ve öğretmenin öğretim materyali hakkındaki görüşleri araştırıldığından, araştırma deneysel gömülü karma yönteme göre yürütülmüştür.

Araştırma sürecinde; deney grubunda geliştirilen Beyin temelli öğrenme yaklaşımına dayalı Web destekli öğretim materyali uygulanılırken, kontrol grubuna ise mevcut öğretim materyali uygulanmıştır. Araştırmanın nicel kısmında hem deney hem de kontrol grubuna; müdahale öncesinde ön test, müdahale sonrasında ise son test uygulanmıştır. Müdahale tamamlandıktan sonra araştırmanın nitel kısmında ise deney grubunda rastgele olarak belirlenen öğrencilerle ve uygulama öğretmeni ile yarı yapılandırılmış mülakatlar yürütülmüştür.

\section{Örneklem}

Karma araştırmalarda araştırmanın örneklemi nicel ve nitel kısımlar için ayrı ayrı belirlenmektedir. $\mathrm{Bu}$ araştırmanın nicel kısmının örneklemini bir ilköğretim okulunun 6. sınıfından; biri deney grubu $(\mathrm{N}=29)$, diğeri kontrol grubu $(\mathrm{N}=29)$ olmak üzere toplam 58 öğrenci oluşturmaktadır. Araştırmanın nitel kısmının örneklemi ise amaçlı örneklem yöntemine göre, Beyin temelli öğrenme yaklaşımına dayalı Web destekli öğretim materyali ile öğretim gören ve rastgele seçilen 10 öğrenci ve bu öğretim materyalini uygulayan öğretmeni oluşturmaktadır. Öğrenci ve öğretmenle yarı yapılandırılmış mülakatlar yürütülmüştür. Araştırmada hem deney hem de kontrol grubunda aynı öğretmen öğretim sürecini yürütmüştür. Yarı yapılandırılmış mülakatlara gönüllü olarak katılan öğrencilerin isimleri, gizli kalması için A, B, C, D, E, F, G, H, I ve J şeklinde kodlanmıştır.

\section{Veri Toplama Araçları}

Veri toplama aracı olarak "Yerkabuğu nelerden oluşur?" ünitesi başarı testi ve yarı yapılandırılmış mülakatlar kullanılmıştır. Araştırmanın nicel verileri, 29 çoktan seçmeli sorudan oluşan Yerkabuğu nelerden oluşur? Ünitesi başarı testi ile elde edilmiştir. Bu testin geliştirilmesi aşamasında ilk olarak, ilgili ünitenin tüm kazanımlarını içeren bir soru havuzu oluşturulmuştur. Testteki soruların kapsam geçerliği, bilimsel geçerliği ve görselliği için 6 fen bilgisi eğitimi uzmanı, 2 fizik öğretmeni, 3 fen bilgisi öğretmeninin görüşleri alınmıştır.

Başarı testindeki soruların okunabilirliği ve anlaşılabilirliği için test; 10 ilköğretim 6 . sınıf öğrencisine pilot olarak uygulanmıştır. Testte anlaşılmayan ifadeler öğrencilerin dönütleri ile düzeltilmiştir. Başarı testinin pilot uygulaması, ilgili ünite işlendikten sonra, 32 ilköğretim 6. sınıf öğrencisi ile yapılmıştır. Test maddelerinin güvenirliğini sağlamak için madde analizi yapılmıştır. Test maddelerinin madde güçlük indeksleri 0,23-0,78 arasında ve maddelerin ayırt edicilik indeksleri 0,21-0,86 arasında değişmektedir. Madde güçlük indeksleri 0,80-1,00 çok kolay; $0,65-0,79$ oldukça 
kolay; $0,35-0,64$ orta düzey; $0,20-0,34$ oldukça zor; $0-0,19$ çok zor olarak yorumlanmaktadır (Özcan, Aydoğan \& Bulut, 2014). 0,65-0,79 arasında 2 soru; 0,35-0,64 arasinda 20 soru; 0,200,34 arasında 6 soru ve $0-0,19$ arasında 1 soru bulunmaktadır. Zor ve çok zor olarak yorumlanan soruların ayırt edicilik indeksleri 0,30'dan büyük olduğu için bu sorular düzeltilerek kullanılmıştır. Madde ayırt edicilik indeksleri -1,00-0,19 arasında olan maddeler ayırt ediciliği düşük olup testte yer almamalıdır. Madde ayırt edicilik indeksleri 0,20-0,29 arasında olan maddeler düzeltilerek teste konulabilir; 0,30-0,39 arasında olanlar düzeltme yapmadan veya küçük düzeltmelerle teste alınabilir; 0,40-1,00 arasında olan maddeler ise teste aynen konulabilir ve ayırt edici maddelerdir (Özcan vd. 2014). Bu araştırmada kullanılan testte 23 sorunun ayırt edicilik indeksi 0,30 ve yukarısında değere sahiptir. Testte ayrıt edicilik indeksi 0,20-0,29 arasında olan 6 madde de düzeltilerek araştırmada kullanılmıştır. Başarı testinin Pearson Korelâsyon güvenirlik katsayısı r $=0,83$ ve Sperman Brown güvenirlik katsayısı da 0,91 olarak hesaplanmıştır.

Araştırmanın nitel verileri, beyin temelli öğrenme yaklaşımına dayalı web destekli öğretim materyalinin uygulama sürecine ilişkin öğretmen ve öğrenci görüşlerini belirlemek için yürütülen yarı yapılandırılmış mülakatlardan elde edilmiştir. Yarı yapılandırılmış mülakat sorularından elde edilen veriler, nicel verileri açıklamak amacıyla kullanılmıştır. Yarı yapılandırılmış mülakat sorularının kapsam geçerliliği için, 3 alan eğitimi uzmanının görüşleri alınmıştır. Uzmanlar, soruların konunun amacına yönelik olduğu yönünde görüş belirtmişlerdir. Ayrıca soruların pilot uygulaması, pilot uygulama öğretmeni ve 5 öğrenci ile yapılmıştır. Böylece mülakat sorularının geçerliği ve güvenirliği sağlanmıştır.

\section{'Yer Kabuğu Nelerden Oluşur?' Ünitesine Yönelik Beyin Temelli Öğrenme yaklaşımına dayalı Web Destekli Öğretim materyali}

Bu çalışma kapsamında hazırlanan, Beyin Temelli Öğrenme yaklaşımına dayalı Web Destekli Öğretim materyalinin geliştirilme aşamaları aşağıda sunulmuştur:

1. İlk olarak materyal geliştirme süreci ile ilgili alanyazın taraması yapılmıştır.

2. Fen ve Teknoloji Dersi Öğretim Programı́nın içeriği ve 'Yer Kabuğu Nelerden Oluşur?' ünitesindeki kazanım ve kavramlar incelenmiş (MEB, 2006); ünitedeki kavramların öğretilmesi, öğrencilerin ilgili ünitede en çok problem yaşadıkları kavramlar ve yaşanan bu problemlerin giderilebilmesi için nelerin yapılabileceği ile ilgili fen bilgisi öğretmenleri ile mülakatlar yürütülmüştür.

3. Ulusal ve uluslararası alanyazında 'Yer Kabuğu Nelerden Oluşur?' ünitesinde yer alan "kayaçlar, kayaç türleri, toprak ve erozyonu" kavramları ile ilgili yapılan çalışmalar incelenmiştir.

4. Araştırmacılar bir araya gelerek Beyin Temelli Öğrenme yaklaşımına dayalı Web Destekli Öğretim materyalinde ne tür etkinliklerden ve ölçme-değerlendirme araçlarından faydalanılabileceğine karar vermiştir. Karar verme sürecinde, 6 . sınıf fen bilgisi öğretmenleri ile yapılan mülakatların analizi ve alanyazın taraması sonucunda elde edilen yanılgılar özellikle dikkate alınmıştır. 
5. Araştırmanın ilerleyen bölümünde sürece Bilgisayar ve Öğretim Teknolojileri Eğitimi (BÖTE) 4. sınıf öğrencileri "Proje Geliştirme ve Yönetimi-II" dersi kapsamında dâhil edilmiş; gruplar halinde ünitede yer alan kazanımlar üzerinde çalışmaları sağlanmıştır. BÖTE Bölümü öğrencilerinden oluşan her bir grup, Web destekli öğretim materyalinin geliştirilmesi ve geliştirilen etkinliklerin web ortamına aktarılması konusunda, kendi kazanımları doğrultusunda araştırmacıların rehberliğinde çalışmıştır. Bu işbirlikli çalışmada 'içerik bilgisi', 'pedagoji bilgisi' ve 'teknoloji bilgisi' birleştirilmiş; disiplinler arası etkileşim ürünü olarak Web destekli öğretim materyali ortaya çıkartılmıştır.

6. Yaklaşık sekiz haftalık bir süreçte Beyin Temelli Öğrenme yaklaşımına dayalı Web Destekli Öğretim materyali pilot çalışmada kullanılabilir hale getirilmiştir.

7. Pilot çalışmayı yapacak fen bilgisi öğretmeni ile görüşülerek Web destekli öğretim materyali tanıtılmış ve materyaldeki öğretim etkinliklerinin nasıl uygulanacağı konusunda bilgilendirme yapılmıştır. Ayrıca öğretmene Beyin Temelli Öğrenme’ye uygun biçimde, Web destekli öğretim materyali ile bir dersin nasıl işleneceğine dair örnek bir uygulama etkileşimli olarak gösterilmiştir.

8. Web destekli öğretim materyalinin tanıtıldığı fen bilgisi öğretmeni ile pilot uygulama gerçekleştirilmiştir.

9. Öğretim materyalinin eksikliklerini belirlemek amacı ile pilot uygulamanın yapıldığı okuldaki öğretmenin dersleri, uygulama süresince gözlemlenmiş ve öğretmen ile öğretim materyaline ilişkin mülakatlar yürütülmüştür.

10. Pilot uygulamanın yapılmasından sonra gerekli değerlendirmeler ve düzeltmeler gerçekleştirilerek, Beyin Temelli Öğrenme yaklaşımına dayalı Web Destekli Öğretim materyaline son hali verilmiştir.

Araştırmada deney grubuna yönelik Web destekli materyali; BTÖ yaklaşımının 12 ilkesi ve bu yaklaşımda gerçekleştirilmesi gereken üç süreç (orkestralanmış daldırma, dingin uyanıklıkve aktifişleme) dikkate alınarak geliştirilmiștir (Caine \& Caine, 1995). Orkestralandırılmış daldırma; öğrencilerin; eski bilgilerini, mevcut yaşantılarını, duygusal özelliklerini ve öğrenme tercihlerini işe koşan zengin bir öğrenme ortamı sunularak; onların yeni bilgilerle karşı karşıya gelmelerinin sağlanmasıdır (Pool, 1997; Leeson \& Willis, 2004; Duman, 2006). Dingin uyanıklık; herhangi bir öğrenme ortamında korkunun alt seviyede, cesaretlendirmenin ise üst seviyede tutulmasıdır. Aktif işleme ise kişinin kendi eğilim ve tutumlarının farkına varması ve nasıl öğrendiğinin bilincinde olması șeklinde açıklanabilmektedir (Caine \& Caine, 1990). WDÖ materyalinde ayrıca; 'grafik örgütleyiciler (kavram haritası, zihin haritası, venn şeması vb.)' ve 'bellek destekleyiciler (akrostiş, akronyum vb.)' gibi BTÖ’ye uygun öğretim stratejilerine yer verilmiştir. Öğrenilen bilgilerin kalıcllğını artırmaya yönelik olarak, ders içeriği sürekli günlük yaşamla ilişkilendirilmiştir. Bununla birlikte ders içeriğinin öğrenilmesinin gerekliliğine dair öğrenciyi ikna etmek ve yeni bilgilerin içselleștirilmesini sağlamak amacıyla KWL diyagramı ("I", "I know", "I want to know" ya da "T’ve learned") kullanılmıştır. Geliştirilen Beyin Temelli Öğrenme yaklaşımına dayalı Web Destekli Öğretim materyalinin bazı ekran görüntüleri Tablo l'de sunulmuştur. 


\section{Tablo I}

Beyin Temelli Öğrenme yaklaşımına dayalı Web Destekli Öğretim Materyalinin Ekran Görüntüleri ve BTÖ Ilkeleri

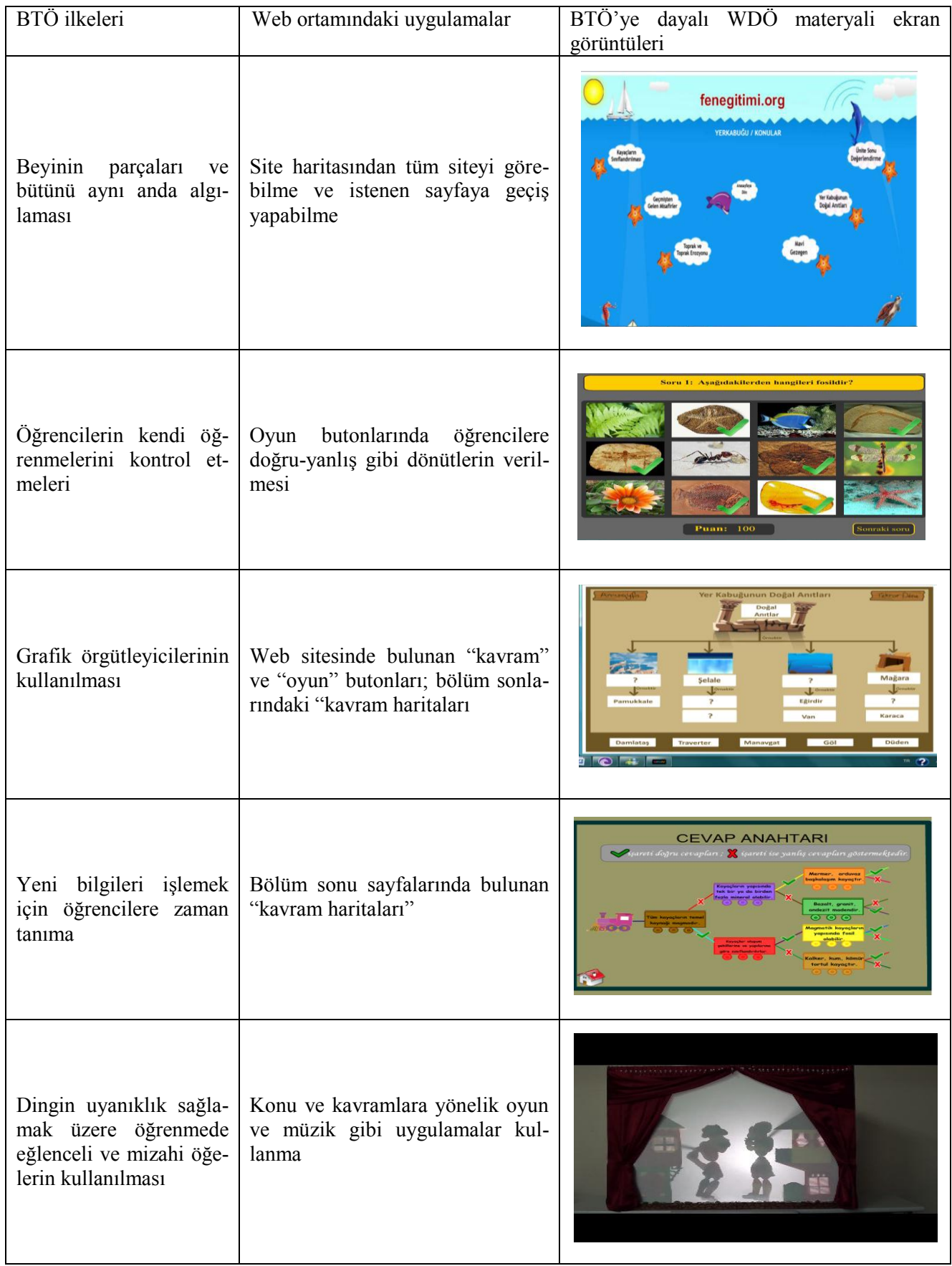


Özetle bu araştırmada geliştirilen Beyin Temelli Öğrenme yaklaşımına dayalı Web Destekli Öğretim Materyalinin ile konu anlatımları; video, power point sunusu, animasyon vb. ile sunulmuş; öğretim sürecinde tanılayıcı dallanmış ağaç, eşleştirme, yapılandırılmış grid, kavram haritası, kavram karikatürleri gibi alternatif ölçme tekniklerinden faydalanılmıştır. Öğrencilerin bu web destekli öğretim materyali ile hem ölçme ve değerlendirme, hem de oyun etkinliklerinde gerekli dönütleri alması sağlanmış; öğrencilere istedikleri zaman bu etkinlikleri tekrar etme imkânı sunulmuştur.

\section{Verilerin Analizi}

“Yerkabuğu nelerden oluşur?” ünitesi başarı testinden elde edilen nicel veriler istatistik paket programı kullanılarak analiz edilmiştir. Araştırmanın verilerinin normal dağılım gösterip göstermediğini belirlerken, grup büyüklügünün 50 'den büyük olması durumunda Kolmogorov Smirnov testi kullanılmaktadır (Büyüköztürk, 2011). Bu nedenle toplanan verilerin normal dağılım gösterme durumu Kolmogorov Smirnov testi ile değerlendirilmiş ve p $>.05$ olarak hesaplanmıştır. Kolmogorov Smirnov testi sonucuna göre nicel veriler parametrik testlerle analiz edilmiştir. Deney ve kontrol gruplarının gruplar arası ilişkisiz örneklemler için bağımsız t-testi ile; gruplar içi ön ve son test puanları, ilişkili örneklemler için bağımlı t-testi ile karşılaştırılmıştır. Araştırmada, Beyin Temelli Öğrenme yaklaşımına dayalı Web Destekli Öğretim materyali ile gerçekleştirilen uygulamaya ilişkin öğrenci ve öğretmen görüşleri ise, yarı yapılandırılmış mülakatlar ile belirlenmiştir. Mülakatlarla elde edilen nitel veriler, içerik analizi ile çözümlenmiş; öğretmen ve öğrenci görüşleri kodlanmış ve kodlardan temalar oluşturulmuştur. Verilerin geçerliğini sağlamak için öncelikle uzmanlar nitel verileri okuyarak kodlamalara birlikte karar vermişlerdir. Ayrıca verilerin geçerliğini sağlamak için öğretmen ve öğrenci ifadelerinden alıntılar sunulmuştur. İçerik analizi ile elde edilen kod ve temalardan matrisler oluşturulmuştur.

\section{Bulgular}

$\mathrm{Bu}$ kısımda başarı testinden ve mülakatlardan elde edilen bulgular, iki alt başlık şeklinde sunulmuştur. Mülakat bulguları, öğrencilerden ve öğretmenden elde edilen bulgular şeklinde gruplandırılmıştır.

'Yer kabuğu nelerden oluşur?' ünitesi başarı testinden elde edilen bulgular

Tablo 2'de deney ve kontrol gruplarının ön test puanlarının bağımsız t-testi ile karşılaştırılmasından elde edilen bulgular verilmiştir.

\section{Tablo 2}

Deney ve Kontrol Grupları Ön Test Puanları Bağımsız T-Testi Karşılaştırması

\begin{tabular}{|c|c|c|c|c|c|c|c|}
\hline Gruplar & $\mathrm{N}$ & Ortalama & Std. Sapma & $\mathrm{sd}$ & $\mathrm{t}$ & $\mathrm{p}$ & $\mathrm{d}$ \\
\hline Deney Grubu & 29 & 14,86 & 5,70 & 56 & $-0,172$ & 0,86 & 0,04 \\
\hline Kontrol Grubu & 29 & 15,10 & 4,98 & & & & \\
\hline
\end{tabular}


Tablo 2'de grupların uygulama öncesi başarılarını karşılaştırmak için uygulanan ön test puanlarına göre grupların ön test puanları arasında anlamlı bir fark olmadı̆̆ı görülmektedir $(t(56)=-0,172 ; p>.05)$. Cohen $d(d=0,04)$ değeri de oldukça küçük bir etki düzeyindedir.

Tablo 3

Deney ve Kontrol Grupları Son Test Puanları Bağımsız T-Testi Karşılaştırması

\begin{tabular}{|c|c|c|c|c|c|c|c|}
\hline Gruplar & $\mathrm{N}$ & Ortalama & Std. Sapma & $\mathrm{sd}$ & $\mathrm{t}$ & $\mathrm{p}$ & $\mathrm{d}$ \\
\hline Deney Grubu & 29 & 20,82 & 4,10 & 56 & 2,21 & 0,03 & 0,57 \\
\hline Kontrol Grubu & 29 & 18,06 & 5,29 & & & & \\
\hline
\end{tabular}

Tablo 3'de deney ve kontrol gruplarının uygulama sonrasında başarılarını karşılaştırmak için uygulanan son test puanlarına göre grupların son test puanları arasında deney grubu lehine anlamlı bir farklılık olduğu görülmektedir $(\mathrm{t}(56)=2,21 ; \mathrm{p}<.05)$. Cohen d değeri de $(\mathrm{d}=0.57)$ orta düzeyde bir etkiye sahip olduğunu göstermektedir.

\section{Tablo 4}

Kontrol Grubu Ön ve Son Test Puanları Bağımlı T-Testi Karşılaştırması

\begin{tabular}{|c|c|c|c|c|c|c|c|}
\hline Kontrol Grubu & $\mathrm{N}$ & Ortalama & Std. Sapma & $\mathrm{sd}$ & $\mathrm{t}$ & $\mathrm{p}$ & $\mathrm{d}$ \\
\hline Ön test & 29 & 15,10 & 4,98 & 28 & $-2,904$ & 0,00 & 0,75 \\
\hline Son test & 29 & 18,06 & 5,29 & & & & \\
\hline
\end{tabular}

Tablo 4'te kontrol grubunun ön ve son test başarı puanları arasında son test lehine anlamlı bir farklılık $(\mathrm{t}(28)=-2,904, \mathrm{p}<.05)$ olduğu görülmektedir. Cohen $\mathrm{d}(\mathrm{d}=0,75)$ yüksek bir etki değerine sahiptir.

\section{Tablo 5}

Deney grubu ön ve son test puanları bağımlı t-testi karşılaştırması

\begin{tabular}{lccccccc}
\hline Deney Grubu & $\mathrm{n}$ & Ortalama & Std. Sapma & sd & $t$ & $\mathrm{p}$ & $\mathrm{d}$ \\
\hline Ön test & 29 & 14,86 & 5,70 & 28 & $-6,393$ & 0,00 & 1,66 \\
\cline { 1 - 3 } Son test & 29 & 20,82 & 4,10 & & & & \\
\hline
\end{tabular}

Tablo 5 'te deney grubunun ön ve son test başarı puanları arasında son test lehine anlamlı bir farklılık $(\mathrm{t}(28)=-2,8 ; \mathrm{p}<.05)$ olduğu görülmektedir. Cohen $\mathrm{d}(\mathrm{d}=1,66)$ oldukça yüksek bir etki değerine sahiptir.

\section{Uygulama Sonunda Deney Grubu Öğrencileri ile Yapılan Yarı Yapılandırılmış Mülakatlardan Elde Edilen Bulgular}

Bu bölümde Web destekli öğretim materyali uygulanan deney grubu öğrencileri ile yapılan mülakattan elde edilen bulgular sunulmuştur. 
Tablo 6

Web destekli Öğretim Materyali Öğretim Sürecinde Öğrencilerin En Çok Beğendikleri Uygulamaya Yönelik Görüşler

\begin{tabular}{|c|c|}
\hline Öğrenci cevaplarından elde edilen kodlar & Öğrenciler \\
\hline Konu anlatımı & C ve E \\
\hline Bilgisayarla öğretim & $\mathrm{A}, \mathrm{B}, \mathrm{D}, \mathrm{G}$ ve $\mathrm{H}$ \\
\hline Görüş bildirmedi & F, I ve J \\
\hline
\end{tabular}

Tablo 7

WDÖ Materyali Ille Işlenen Ünitenin Diğer Ünitelerden Farkına Yönelik Öğrenci Görüşleri

\begin{tabular}{|c|c|c|c|c|c|c|c|c|c|c|c|}
\hline $\begin{array}{l}\text { Ŏgrenci } \\
\text { Kodlar }\end{array}$ & $\mathrm{A}$ & B & $\mathrm{C}$ & $\mathrm{D}$ & $\mathrm{E}$ & F & G & $\mathrm{H}$ & I & $\mathrm{J}$ & $\begin{array}{l}\text { İfade Siklığ } \\
(\mathrm{N}=10)\end{array}$ \\
\hline Anlamayı kolaylaştırma & * & * & & * & & & & & & * & 4 \\
\hline Pekiştireç sağlama & & & & * & & & & & & & 1 \\
\hline Motivasyonu sağlama ve dikkat çekme & & & $*$ & & & & * & & & & 2 \\
\hline Eğlenceli öğrenmeyi sağlama & & * & & & * & * & & * & * & & 5 \\
\hline Görsellik sağlaması & & & & & & & & & & * & 1 \\
\hline Dersin bilgisayarda işlenmesi & ${ }^{\star}$ & & & & & & & * & & * & 3 \\
\hline
\end{tabular}

Diğer Fen ve Teknoloji ünitelerinin işlenişi ile karşılaştırıldığında A, B, D ve J kodlu öğrenciler Web destekli öğretim materyalinin anlamayı kolaylaştırdığını; D kodlu öğrenci pekiştireç sağladığını; C ve G kodlu öğrenciler motivasyonu sağladığını ve dikkat çektiğini; B, E, F, H ve I kodlu öğrenciler eğlenceli öğrenmeyi sağladığını ve J kodlu öğrenci görsellik sağladığını belirtmiştir (Tablo 7). A, H ve J kodlu öğrenciler ise derslerin bilgisayarla işlenmesini, diğer ünitelerden farklı bir durum olarak nitelendirmiştir.

\section{Tablo 8}

Web Destekli Öğretim Materyali ile Isşlenen Derslere illişkin Öğrenci Görüşleri

\begin{tabular}{ccccc}
\hline $\begin{array}{c}\text { Öğrenci } \\
\text { Kodları }\end{array}$ & Materyalde ilgi çeken konular & Materyale ilişkin öneriler & \multicolumn{2}{c}{$\begin{array}{c}\text { Materyal ile öğrenme ve } \\
\text { ögrenme gerekçesi }\end{array}$} \\
\hline A & Konu anlatımları anlamlı ve ikna edici & Daha fazla deney & ${ }^{*}$ & Kolay anlama \\
\hline B & Kayaç döngüsü konusu & Fosillerin yaşını bulmak isterdim & $*$ & Süreç daha iyi \\
\hline C & Kayaçlar & Daha çok bilgi olsun isterim & $*$ & Kolay anlama \\
\hline D & Yapılan etkinlikler, oyun ve bulmacalar & - & ${ }^{*}$ & Bilgisayarla işleme \\
\hline E & Kayaçlar & Daha fazla bilgi & ${ }^{*}$ & Eğlenceli \\
\hline F & - & - & ${ }^{*}$ & Kolay anlama \\
\hline G & Yer kabuğu & - & ${ }^{*}$ & - \\
\hline H & Deneyler & Daha fazla deney & $*$ & Daha fazla deney \\
\hline I & - & - & $*$ & Eğlenceli \\
\hline J & - & - & $*$ & Kolay anlama \\
\hline
\end{tabular}

* Bu uygulamadan sonra da, WDÖ materyali ile öğrenmek istiyorum. 
Tablo 8'de C ve E kodlu öğrenciler "kayaçlar"; B kodlu öğrenci "kayaç döngüsü"; A kodlu öğrenci konu anlatımlarının; D kodlu öğrenci yapılan etkinliklerin, oyun ve bulmacaların; G kodlu öğrenci yer kabuğu konusunun; $H$ kodlu öğrenci ise deneylerin ilgilerini çektiğini belirtmiştir. F, I ve J kodlu öğrenciler bu konuda herhangi bir görüş belirtmemiştir.

Web destekli öğretim materyaline ilişkin önerileri sorulduğunda; A ve H kodlu öğrenciler, öğretim sürecinde daha fazla deney görmek istediklerini ifade etmişlerdir (Tablo 8). B kodlu öğrenci, fosillerin yaşını bulabilecek bir uygulamayı görmek istediğini ifade ederken; C ve $\mathrm{E}$ kodlu öğrenciler ise yer kabuğu ünitesinde daha çok bilgi görmek istediklerini ifade etmişlerdir. D, F, G, I ve J kodlu öğrenciler ise bu konuda görüş bildirmemişlerdir.

Öğrencilerin tamamı bundan sonraki derslerinin; web destekli yürütülmesini istediklerini ifade etmişlerdir (Tablo 8). A, C, F ve J kodlu öğrenciler Web destekli öğretim materyali ile kolay anladıklarını; B kodlu öğrenci sürecin daha iyi işlediğini; D kodlu öğrenci bilgisayarla işledikleri için derslerin web destekli olmasını istediğini belirtmiş̧ir. E ve I kodlu öğrenciler dersleri eğlenceli bulduklarını ifade ederken; $\mathrm{H}$ kodlu öğrenci daha fazla deney yaptıkları için derslerin web destekli yürütülmesini istediğini ifade etmiştir. G kodlu öğrenci ise bundan sonraki derslerinin web destekli yürütülmesini istemekle birlikte nedeni hakkında herhangi bir görüş belirtmemiştir.

Öğrencilerin tamamı derslerin işlenişinde herhangi bir eksiklik görmediklerini ve herhangi bir problem olmadığını ifade etmişlerdir.

\section{Uygulama Sonunda Uygulama Öğretmeni ile Yapılan Mülakattan Elde Edilen Bulgular}

Uygulama öğretmeninin Beyin Temelli Öğrenme yaklaşımına dayalı Web Destekli Öğretim Materyal ile ilgili görüşleri Tablo 9'da sunulmuştur. 


\section{Tablo 9}

Uygulama Öğretmeninin Beyin Temelli Öğrenme yaklaşımına dayalı Web Destekli Öğretim Materyalinin Ile Yapılan Öğretim Sürecine Yönelik Görüşleri

\begin{tabular}{|c|c|c|}
\hline Tema & Kodlar & Öğretmenin ifadesinden alıntılar \\
\hline \multirow{7}{*}{ 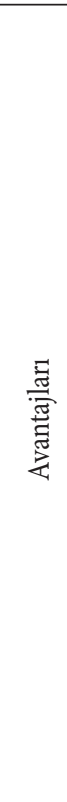 } & Öğretim sürecinde görselliği sağlaması & $\begin{array}{l}\text { "Öğrencilerin görerek öğrenmeleri daha kolay olduğu için, } \\
\text { daha rahat bir öğrenme ortamı oluşturmaktadır. Web destekli } \\
\text { materyaller fen ve teknoloji dersinde mutlaka olmalıdır" }\end{array}$ \\
\hline & Öğrenmeyi kolaylaştırması & $\begin{array}{l}\text { "Web destekli uygulama daha çok görsel zekâya hitap ettiği için } \\
\text { öğrenmeyi kolaylaştırmakta..." }\end{array}$ \\
\hline & Eğlenerek öğrenmeyi sağlaması & $\begin{array}{l}\text { "Bu materyal ile öğrencilerin öğrenmesi biraz daha kolaylaştı ve } \\
\text { dersin işlenişi daha zevkli hale gelmiştir..." }\end{array}$ \\
\hline & 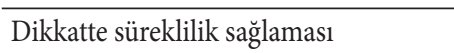 & “...Dikkati devamlı derse odaklayabiliyor..." \\
\hline & Oyun ve soruların dikkat çekici olması & $\begin{array}{l}\text { “... Süreçte öğrencilerin oyuna ve sorulara karşı ilgisinin daha } \\
\text { fazla olduğunu gördüm...” }\end{array}$ \\
\hline & Öğretmenin işini kolaylaştırması & $\begin{array}{l}\text { "Hem öğretmene hem de öğrenciye dersin işlenişi açısından } \\
\text { kolayllk sağlamaktadır... Öğretmene daha fazla kolaylık sağlıyor. } \\
\text { Çünkü öğretmen daha az çalışıyor" }\end{array}$ \\
\hline & Soyut kavramları somutlaştırması & $\begin{array}{l}\text { “... Öğrencilerin bazı soyut kavramları somut halde görmeleri } \\
\text { öğrenmeyi kolaylaştırmıştır." }\end{array}$ \\
\hline \multirow{4}{*}{ 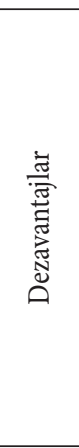 } & $\begin{array}{l}\text { Psiko-motor becerileri geliştirmeyi } \\
\text { desteklememesi }\end{array}$ & $\begin{array}{l}\text { “... Fakat öğrencilerin diğer özelliklerini pek ön plana } \\
\text { çıkaramamaktadır. Öğrencilerin etkinlikleri sınıf } \\
\text { ortamında kendilerinin yapmalarının daha faydalı olacağını } \\
\text { düşünüyorum....” }\end{array}$ \\
\hline & $\begin{array}{l}\text { WDÖ'in her derste kullanılmasının } \\
\text { dersin sıkıcı olmasına sebep olması }\end{array}$ & $\begin{array}{l}\text { “.. Öğrencinin belli düzeyden sonra sıkıldığını gördüm. } \\
\text { Öğrencinin dikkati dağılıyor” }\end{array}$ \\
\hline & Teknik sorunlar yaşanması & $\begin{array}{l}\text { "Bazı teknik hatalar yaşandı. Bazı videoların açılmaması, } \\
\text { istendiğinde durdurulamaması, ses sorunu gibi sorunlar dersin } \\
\text { akışını bozmuştur." }\end{array}$ \\
\hline & Zaman kaybi olması & $\begin{array}{l}\text { "Bazı teknik hatalar yaşandı... Bu da zaman kaybına neden } \\
\text { olmuştur." }\end{array}$ \\
\hline \multirow{4}{*}{ 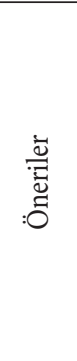 } & İçerik zenginleştirilmeli & $\begin{array}{l}\text { "WDÖ materyalinde detaylı bilgi sunulmamış. Bazı bilgilerin } \\
\text { eksik olduğunu gördüm. Öğrencilerin konuyu tam olarak } \\
\text { kavramaları için içerik biraz daha zenginleştirilebilir. }\end{array}$ \\
\hline & Konu anlatımı detaylandırılmalı & $\begin{array}{l}\text { "Gösterilen videoların içeriğinin daha zengin olmasının ve } \\
\text { öğrencilerin konu içine dâhil edilmesinin daha faydalı olacağını } \\
\text { düşünüyorum. Konu anlatımı biraz daha detaylı olabilir." }\end{array}$ \\
\hline & Etkileşimlilik arttırılmalı & $\begin{array}{l}\text { "... Öğrenciyi daha aktif hale getirerek konuyu öğrenciyle } \\
\text { beraber ișlemek daha faydalı olacaktır..." }\end{array}$ \\
\hline & Tekrar amaçlı kullanılmalı & "... Bu materyal daha çok konu tekrarı için kullanılabilir..." \\
\hline
\end{tabular}

Tablo 9'da uygulama öğretmeninin Beyin Temelli Öğrenme yaklaşımına dayalı Web Destekli Öğretim Materyali ile ilgili görüşleri incelendiğinde; Web destekli öğretim materyalinin 
avantajları, dezavantajları ve uygulamaya ilişkin öneriler temalarında görüş bildirdiği görülmektedir. Uygulama öğretmeni Web destekli öğretim materyalinin avantajları teması altında; görselliği sağlaması, öğrenmeyi kolaylaştırması, eğlenerek öğrenmeyi sağlaması, dikkatte sürekliliği sağlaması, oyunlar ve soruların dikkat çekici olması, öğretmenin işini kolaylaştırması ve soyut kavramların somutlaştırılması kodlarına yönelik açıklamalarda bulunmuştur.

Öğretmenin Web destekli öğretim materyalinin dezavantajları ile ilgili görüşleri incelendiğinde; psiko-motor becerileri geliştirmeyi desteklememesi, her derste kullanılmasının sıkıcı olması, teknik sorunlar yaşanması ve zaman kaybı olması kodlarına yönelik görüşler belirttiği belirlenmiştir. Öğretmenin WDÖ materyaline yönelik öneriler teması altında ise içerik zenginleştirilmeli, konu anlatımı detaylandırılmalı, etkileşimlilik arttırılmalı ve tekrar amaçlı kullanılmalı şeklinde kodlara vurgu yaptı̆̆ı görülmüş̧ür.

\section{Tartışma ve Sonuç}

Öğrencilerin 'Yer kabuğu nelerden oluşur?' ünitesi başarı testi sonuçları incelendiğinde ön test puanları arasında anlamlı bir farklılı̆̆ın bulunmadığı görülmüştür. Öğrencilerin 'Yer kabuğu nelerden oluşur?' ünitesi ön test başarı puanları dikkate alındığında, iki grubun da testteki ortalama puanlarının birbirine oldukça yakın olduğu belirlenmiştir. İki grubun 'Yer Kabuğu Nelerden Oluşur?' ünitesindeki t - testi sonuçlarına göre ön test puanları arasında anlamlı bir farklılık olmaması; deney ve kontrol grubu öğrencilerinin öğretimden önce aynı seviyede oldukları şeklinde yorumlanabilir. Bu durum Beyin Temelli Öğrenme yaklaşımına dayalı Web Destekli Öğretim materyalinin etkisinin karşılaştırılması açısından önemlidir. Hem deney hem de kontrol gruplarının ön ve son test puanları, gruplar içinde bağımlı $t$ testi ile karşılaştırıldığında ise, her iki grupta da son test lehine anlamlı bir farklılık olduğu görülmektedir. Bu durum; hem Beyin Temelli Öğrenme yaklaşımına dayalı Web Destekli Öğretim materyalinin, hem de mevcut öğrenme yaklaşımının ve materyallerinin öğrenci başarısını arttırmada etkili olması ile açıklanabilir. Keleş̧in (2007) Beyin Temelli Öğrenme yaklaşımına dayalı Web Destekli Öğretim materyalinin öğrenci başarısına etkisi ile ilgili yaptığı çalışmasında, geliştirilen Web destekli öğretim materyali uygulandıktan sonra öğrenci başarılarında artış sağlandığı belirlenmiştir. Aynı şekilde Taş’ın (2006) yaptığı çalışmada da Web destekli öğretim materyalinin, öğrencilerin başarı düzeylerinde artış sağladığı belirlenmiştir. Her iki araştırmadan ortaya çıkan sonuç, bu araştırmanın bulgularını destekler niteliktedir. Bu çalışmada yer alan grupların son test puanları incelendiğinde, deney grubu lehine anlamlı bir farklıllğın olduğu tespit edilmiştir. Uygulamalar sonrasinda 'Yer kabuğu nelerden oluşur?' ünitesinde deney ve kontrol grubu öğrencilerinin ortalamalarının arttığı görülmektedir. Deney ve kontrol gruplarının son başarı testi puanları bağımsız $\mathrm{t}$ testi ile karşılaştırıldığında ise deney grubu lehine anlamlı bir farklılık olması, deney grubunda uygulanan Beyin Temelli Öğrenme yaklaşımına dayalı Web Destekli Öğretim materyalinin öğrencilerin başarılarını arttırmada mevcut öğrenme yaklaşımına ve öğretim materyallerine göre daha etkili olması ile yorumlanabilir. Nitekim Şenel Çoruhlu, Er Nas \& Keleş่in (2016) ışık konusunun öğretimi ile ilgili yaptıkları çalışmalarında, Web destekli 
gerçekleştirilen öğretim sürecinin geleneksel öğretim sürecine göre öğrencilerin başarılarını olumlu yönde etkilediği belirlenmiştir.

Beyin temelli öğrenme yaklaşımına dayalı öğretimin, öğrencilerin sentez ve değerlendirme gibi üst düzey düşünme becerilerinin geliştirilmesinde (Çelebi \& Afyon, 2011); öğrencilerin başarılarını arttırmada ve öğrenmenin kalıcılığının sağlanmasında geleneksel öğretim yöntemine göre daha etkili olduğu yapılan araştırmalarda tespit edilmiştir (Akyürek \& Afacan, 2013; Sülün, Yurttaş \& Şerenli, 2008; Odabası \& Celkan, 2010; Duman, 2010; Tafti \& Kadkhodaia, 2017). Ayrıca WDÖ materyalleri ile yapılan öğretimin öğrencilerin; kavramsal öğrenmelerini geliştirdiği (Sun, Looi \& Xie, 2014) ve başarılarını arttırdığı da yapılan çalışmalarla belirlenmiştir (Taş, Apaydın \& Çetinkaya, 2011; Taş, 2011; Ural \& Ercan, 2015). BTÖ yaklaşımında da belirtildiği üzere en kalıcı öğrenmeler, beynin her iki lobunun da uyarılması ile gerçekleştirilebilmektedir (Oktay \& Çakır, 2013). Bu araştırmada deney grubu öğrencilerinin, kontrol grubu öğrencilerinden daha başarılı olmaları; deney grubunda uygulanan Beyin temelli öğrenmeye dayalı web destekli öğretim materyalinde, beynin hem sağ hem de sol lobunu uyaran etkinliklere yer verilmesinden kaynaklanmış olabilir.

Araştırmanın verilerinden hesaplanan etki büyüklükleri incelendiğinde; kontrol grubunda uygulanan geleneksel öğretimin, öğrenci başarısı üzerinde orta düzeyde bir etkiye sahip olduğu; deney grubunda uygulanan Beyin temelli öğrenmeye dayalı web destekli öğretim materyalinin ise geniş düzeyde bir etkiye sahip olduğu tespit edilmiştir. Benzer şekilde Gözüyeşil \& Dikici (2014), inceledikleri 31 çalışmanın meta analizi sonucunda, BTÖ’nün öğrencilerin akademik başarısı üzerinde orta düzeyde bir etkiye $(\mathrm{d}=0.640)$ sahip olduğunu ortaya koymuştur.

Öğrencilerin Beyin temelli öğrenmeye dayalı web destekli öğretim materyali ile ilgili görüşlerinden elde edilen bulgular incelendiğinde, öğrencilerin konu anlatımının bilgisayar kullanılarak yapılmasından memnun kaldıkları belirlenmiştir. Benzer şekilde yapılan araştırmalarda Web destekli öğretimin, öğrencilerin bilgisayar ve internet kullanılmasına yönelik olumlu tutum geliştirmelerinde etkili olduğu sonucunu desteklemektedir (Altunçekiç \& Aksu, 2011; Usta, 2011). Öğrenciler Beyin Temelli Öğrenme yaklaşımına dayalı Web Destekli Öğretim Materyali ile gerçekleştirilen öğretim sürecinin, diğer konuların işlenme sürecinden farklı olarak; anlamalarını kolaylaştırdığı, görsellik sağladığı, motivasyon sağladığı ve dikkat çektiği, pekiştireç sağladığı, eğlenceli bir şekilde öğrenmeye katkı sağladığı yönünde görüş belirtmiştir. Ayrıca öğrenciler, bundan sonraki öğretim sürecinde de Web destekli öğretim materyali ile öğrenmek istediklerini ifade etmişlerdir. Öğretmenin de, öğrenci görüşlerine benzer şekilde Beyin temelli öğrenme yaklaşımına dayalı Web destekli öğretim materyalinin; anlamayı kolaylaştırma, somutlaştırma, eğlenceli öğrenmeyi sağlama gibi avantajlara vurgu yaptığı görülmektedir. Beyin temelli öğrenmenin sınıfta duygusal ortam oluşturarak öğrenmeyi kolaylaştırdığı, tamamen öğrenen merkezli bir yaklaşım olduğu, öğrenmeyi anlamlı ve eğlenceli bir hale getirdiği, öğretmen - öğrenci arasında iyi ilişkiler kurmasını sağladığı bilinmektedir (Thomas \& Swamy, 2014). Şengel’in (2005) araştırma sonucu ise WDÖ ortamlarının öğrencilerin öğrenmesi üzerinde pozitif bir etkiye sahip olduğunu desteklemektedir. WDÖ; ses ve görüntü 
ile desteklenen animasyonlarla, öğrencilere zengin öğrenme ortamları sunmakta ve öğrencilerin birden fazla duyu organına hitap ederek kalıcılığı sağlamaktadır (Yılmaz, 2002; Cüez, 2006).

Araştırmada öğrenciler Beyin Temelli Öğrenme yaklaşımına dayalı Web Destekli Öğretim Materyalinin ile ilgili olumlu görüşler belirtirken, uygulama öğretmeni öğrencilerin etkinlikleri sınıf ortamında kendilerinin bizzat yaparak yaşayarak öğrenmelerinin daha etkili olacağını ve Web destekli öğretim materyalinin öğrencilerin psiko-motor becerilerini geliştirmeyi desteklemediğini ifade etmiştir. Yapılan çalışmalarda ise Beyin Temelli Öğrenme yaklaşımına dayalı Web Destekli Öğretim Materyalinin öğrencilerin ilgilerini çektiği ve öğrenme sürecinde aktif kalmalarını sağladığı belirtilmektedir (Light \& Polin, 2010). Ayrıca uygulama öğretmeni Web destekli öğretim materyalinin, her derste sürekli kullanılmasının sonucu olarak, öğrencilerin sıkılabileceği yönünde görüş belirtmiştir. Uygulama öğretmeni Web destekli öğretim materyalinin uygulanması sürecinde, internet hızı nedeniyle videoların yavaş açılması gibi teknik sorunlar yaşandığını ve bu durum nedeniyle ders esnasında zaman kayıplarının yaşandığını ifade etmiştir. Yapılan araştırmaların sonuçları da; WDÖ sırasında internet bağlantısının yeterli olmamasının ve öğretmenlerin bilgi ve iletişim teknolojinin kullanımı konusundaki eksikliklerinin, web destekli materyal ile ders işlenmesini zorlaştırdığını göstermektedir. Belirtilen bu sebeplerden dolayı öğretmenlerin web destekli araçları kullanma noktasında, daha az pozitif tutum sergiledikleri ifade edilmektedir (Afshari, Bakar, Luan, Samah \& Fooi, 2009; Salehi \& Salehi, 2012).

\section{Öneriler}

'Yer kabuğu nelerden oluşur?' ünitesi ile ilgili geliştirilen Beyin Temelli Öğrenme yaklaşımına dayalı Web Destekli Öğretim Materyalinin ilköğretim 6. sınıf öğrencilerinin Fen ve Teknoloji derslerinde kullanabilecekleri bir materyal olduğu görülmektedir. Bu materyal internet üzerinden öğrenci ve öğretmenlerin ulaşabilecekleri şekilde hazırlanmıştır. Öğrenciler ve öğretmenler bu materyali kullanabilirler. Ancak bu ve benzeri WDÖ materyalleri belirli periyotlarla güncellenmelidir. WDÖ materyalleri hazırlanırken özellikle öğrencinin daha fazla etkileşimde olabileceği uygulamalara yer verilmelidir.

Web destekli öğretim materyalinin daha etkili uygulanması için, okullardaki Bilişim Teknolojileri öğretmenleri tarafından kullanıcılara gerekli rehberlik ve teknik destek sağlanabilir. Aksi takdirde bu araştırmada uygulama öğretmenin de belirttiği gibi teknik sorunların yaşanması, öğrencilerin derste sıkılmasına ve öğretim sürecinde zaman kaybına sebep olabilir.

$\mathrm{Bu}$ tür materyallerin geliştirilmesinde, ilgili alanyazının taranması ve materyalin kullanıcıları olan öğretmenlerin görüşlerinin alınması önemlidir. Öğretmenlerin yanı sıra, ortaya çıkacak ürünün birebir kullanıcısı olacak öğrencilerin de görüşlerinin alınması, daha nitelikli bir materyalin geliştirilmesine katkı sağlayacaktır.

$\mathrm{Bu}$ çalışma kapsamındaki web destekli öğretim materyali, beyin temelli öğrenme yaklaşımına uygun olarak geliştirilmiştir. Benzer materyallerin, eğitim alanında ortaya çıkan farklı yaklaşımlar temel alınarak gerçekleştirilebilmesi mümkündür. Sağlam bir kuramsal altyapının kullanılması, 
WDÖ materyalinin daha nitelikli olmasına, pedagojik yönden güçlü bir şekilde tasarlanmasına katkı sağlayacaktır.

Fen öğretimine yönelik yapılacak bilgisayar ve web destekli öğretim materyallerinin geliştirilmesine ilişkin yeni çalışmalarda, Bilgisayar ve Öğretim Teknolojileri Eğitimi Bölümü ile işbirlikli çalışmaların devamının getirilmesi yararlı olacaktır. Ancak bu işbirlikli çalışmalarda koordinasyon sağlanması, uyumlu bir sürecin gerçekleştirilmesi başarılı ürünlerin ortaya koyulabilmesi için proje geliştirme ve yönetimi konusunda deneyimli uzmanların çalışmaları koordine etmesi tavsiye edilmektedir. 


\section{Kaynakça}

Afshari, M., Bakar, K. A., Luan, W. S., Samah, B. A., \& Fooi, F. S. (2009). Factors affecting teachers' use of information and communication technology. International Journal of Instruction, 2(1), 77-104.

Akyürek, E \& Afacan, Ö. (2013). The effect of brain-based learning approach which applied to 8th grade science and technology classes on students' academic achievement. The Journal of Academic Social Science Studies, 6(1), 75-98.

Altunçekiç, A. \& Aksu, L. (2011). Web destekli öğrenme ortamlarının internet kullanımına yönelik tutum düzeyleri üzerine etkisi. Kastamonu Eğitim Dergisi, 19(1), 239-250.

Ayas, A. \& Uşak, M. (2006). The effect of conceptual change texts instructions on overcoming prospectice science teachers' misconceptions of photosynthesis and respiration in plants. International Journal of Environmental and Science Education, 1(1), 78-103.

Baki, A. \& Gökçek, T. (2012). Karma Yöntem Araştırmalarına Genel Bir Bakış. Elektronik Sosyal Bilimler Dergisi, 11(42), 1-21.

Birisci, S. \& Metin, M. (2009). Fen konularına yönelik web sayfası hazırlama öğretmen adaylarının bilgisayar teknolojisini kullanabilme becerilerini nasıl etkiler? Necatibey Eğitim Fakültesi Elektronik Fen ve Matematik Eğitimi Dergisi, 3(2), 74-93.

Büyüköztürk, Ş. (2011). Sosyal Bilimler İçin Veri Analizi El Kitabı. Pegem Akademi, Ankara.

Büyüköztürk, Ş., Kılıç Çakmak, E., Akgün, Ö. E., Karadeniz, Ş., \& Demirel, F. (2012). Bilimsel Araştırma Yöntemleri. Pegem Akademi, Ankara.

Blake, A. (2004). Helping young children to see what is relevant and why: Supporting cognitive change in earth science using analogy. International Journal of Science Education, 26(15), 1855-1873.

Blake, A. (2005). Do young children's ideas about the Earth's structure and processes reveal underlying patterns of descriptive and causal understanding in earth science? Research in Science \& Technological Education, 23(1), 59-74.

Bozkurt, O., Salman Akın, B. \& Uşak, M. (2004). İlköğretim 6., 7. ve 8. Sınıf öğrencilerinin "Erozyon" hakkındaki ön bilgilerinin ve kavram yanılgılarının tespiti. Gazi Üniversitesi Kırşehir Eğitim Fakültesi, 5(2), 277-285.

Caine, R. N. ve Caine, G. (1990). Understanding a Brain-Based Approach to Learning and Teaching. Educational Leadership, 48(2), 66-70.

Caine, R. N. \& Caine, G. (1994). Making connections: Teaching and the human brain. New York: AddisonWesley.

Caine, R. N. \& Caine, G. (1995). Reinventing schools through brain-based learning. Educational Leadership, $52,43-47$.

Creswell, J. W. (2006). Understanding Mixed Methods Research - Chapter 1. http://www.sagepub.com/sites/ default/files/upm-binaries/10981_Chapter_1.pdf Web adresinden 16 Temmuz 2015 tarihinde edinilmiştir.

Cüez, T. (2006). İlköğretim 8. sınıflarda fen bilgisi dersinde web tabanlı öğretim desteğinin öğrenci başarısına etkisi. Yayımlanmamış Yüksek Lisans Tezi, Dokuz Eylül Üniversitesi Eğitim Bilimleri Enstitüsü, İzmir.

Çayan, Y., \& Karslı, F. (2015). 6. sınıf öğrencilerinin fiziksel ve kimyasal değişim konusundaki kavram yanılgılarının giderilmesinde probleme dayalı öğrenme yaklaşımının etkisi. Kastamonu Eğitim Dergisi, 23(4), 1433-1448.

Çelebi, K. \& Afyon, A. (2011). İlköğretim fen bilgisi dersinde uygulanan beyin temelli öğrenme yaklaşımının öğrencilerin başarılarına etkisi. Selçuk Üniversitesi Ahmet Keleşoğlu Eğitim Fakültesi Dergisi, 31, 169-182. 
Dal, B. (2009). An investigation into the understanding of earth science among students teachers. Educational Sciences: Theory \& Practice, 9(2), 597-606.

Demirel, Ö. (2011). Kuramdan uygulamaya eğitimde program geliştirme. Ankara: Pegem Akademi Yayınları.

Demirel, Ö., Erdem, E., Koç, F., Köksal, N., \& Şendoğdu, M. C. (2002). Beyin temelli öğrenmenin yabanc1 dil öğretiminde yeri. Marmara Üniversitesi Atatürk Eğitim Fakültesi Eğitim Bilimleri Dergisi, 15, 123-136.

Dove, J. (1997), Student ideas about weathering and erosion. International Journal of Science Education, 19(8), 971-980.

Duman, B. (2006, July). The effect of brain-based instruction to improve on students' academic achievement in social studies instruction. Paper presented at the 9th International Conference on Engineering Education, San Juan, Puerto Rico.

Duman, B. (2010). The effects of brain-based learning on the academic achievement of students with different learning styles. Educational Sciences: Theory \& Practice, 10(4), 2077-2103.

Durmaz, H. (2004). Nasıl bir fen eğitimi istiyoruz?. Yaşadıkça Eğitim, (83-84), 38-40.

Ecevit, T., \& Şimşek, P. Ö. (2017). Öğretmenlerin fen kavram öğretimleri, kavram yanılgılarını saptama ve giderme çalışmalarının değerlendirilmesi. İlköğretim Online, 16(1).

Erol, M. (2017). Beyin Temelli Öğrenme Modeline Uygun Hazırlanan Öğretim Aktivitelerinin Öğrencilerin Matematik Başarısına Etkisi. Yayımlanmamış Yüksek Lisans Tezi, İstanbul Üniversitesi Eğitim Bilimleri Enstitüsü, İstanbul.

Ford, D. J. (2005). The challenges of observing geologically: Third graders' descriptions of rock and mineral properties. Science Education, 89, 276- 295.

Gökçek, T., Babacan, Z., Kangal, E., Çakır, E. \& Kül, Y. (2013). 2003-2013 Yılları Arasında Türkiye’de Karma Araştırma Yöntemiyle Yapılan Eğitim Çalışmalarının Analizi. The Journal of Academic Social Science Studies 6 (7): 435-456.

Gözüyeşil, E. \& Dikici, A. (2014). The effect of brain based learning on academic achievement: a metaanalytical study. Educational Sciences: Theory \& Practice, 14(2), 642-648.

İnci, N., Zorlu, Y. \& Çil, E. (2009). İlköğretim 6. Sınıf öğrencilerinin "Yer kabuğu nelerden oluşur?” ünitesindeki kavramlarının anlaşılma düzeyleri ile kavram yanılgılarının belirlenmesi ve bazı değişkenler açısından incelenmesi. Education Sciences, 4(4), 1160-1170.

İpek Akbulut, H., Şahin, Ç. \& Çepni, S. (2013). İş ve enerji konusu ile ilgili kavramsal değişimin incelenmesi: İkili yerleşik öğrenme modeli örneği. Mehmet Akif Ersoy Üniversitesi Eğitim Fakültesi Dergisi, 13(25), $241-268$.

Keleş, E. (2007). Altıncı sınıf kuvvet ve hareket ünitesine yönelik beyin temelli öğrenmeye dayalı web destekli öğretim materyalinin geliştirilmesi ve etkililiğinin değerlendirilmesi. Yayımlanmamış Doktora Tezi, Karadeniz Teknik Üniversitesi Fen Bilimleri Enstitüsü, Trabzon.

Köseoğlu, F. \& Kavak, N. (2001). Fen öğretiminde yapılandırıcı yaklaşım. G.Ü. Gazi Eğitim Fakültesi Dergisi, 21(1), 139-148.

Leeson, M. \& Willis, J. (2004). What's The Buzz About? Brain-Based Learning for All Students. http://www. naz.edu:900/ include/pdfs/poster/Brain\%20based.pdf, İnternetten alınıș tarihi: 02 Ocak 2010.

Light, D. \& Polin, D. K. (2010). Integrating Web 2.0 Tools into the Classroom: Changing the Culture of Learning. Center for Children and Technology, Education Development Center, Inc.

Milli Eğitim Bakanlığı (2006). İlköğretim fen ve teknoloji dersi (6, 7 ve 8. sınıflar) öğretim programı. Ankara: MEB Yayınevi. 
Odabas1, B. \& Celkan, H.Y. (2010). The effects of brain based learning approach on the success of 12th grade of students, Ç.Ü. Sosyal Bilimler Enstitüsü Dergisi, 19(3), 87-104.

Oktay, S. \& Çakır, R. (2013). Teknoloji destekli beyin temelli öğrenmenin öğrencilerin akademik başarıları, hatırlama düzeyleri ve üstbilişsel farkındalık düzeylerine etkisi. Journal of Turkish Science Education, 10(3), 3-23.

Özcan, K.V., Aydoğan, Y. \& Bulut, İ. (2014). Gaziosmanpaşa Üniversitesi Tip Fakültesi’nde Uygulanan Çoktan Seçmeli Sınavların Betimsel Analizi. Gaziosmanpaşa Üniversitesi Tip Fakültesi Dergisi, 6(4), 281-294.

Özden, M., (2005). Fen bilgisi dersinde beyin temelli öğrenmenin akademik başarıya ve hatırlama düzeyine etkisi. Yayımlanmamış Yüksek Lisans Tezi, Anadolu Üniversitesi Eğitim Bilimleri Enstitüsü, Eskişehir.

Özden, M. \& Gultekin, M. (2008). The Effects of Brain-Based Learning on Academic Achievement and Retention of Knowledge in Science Course. Electronic Journal of Science Education, 12(1), 1-17.

Paliç, G., \& Akdeniz, A. R., (2012). Beyin temelli öğrenmeye dayalı web destekli bir öğretim materyalinin tasarlanması ve değerlendirilmesi. Necatibey Eğitim Fakültesi Elektronik Fen ve Matematik Eğitimi Dergisi (EFMED), 6(1), 67-93.

Plano Clark, V. L., Huddleston-Casas, C.A., Churchill, S.L., O’Neil Green, D. \& Garrett, A.L. (2008). Mixed Methods Approaches in Family Science Research. Journal of Family Issues, 29: 1543-1566.

Pool, C. R. (1997). Maximizing Learning, A Conversation with Nummela Caine. Educational Leadership, 54(6), 11-15.

Reinfried, S. (2006). Conceptual Change in Physical Geography and Environmental Sciences through Mental Model Building: The Example of Groundwater. International Research in Geographical and Environmental Education, 15(1), 41-61. 